\title{
Infectious disease experts expect the unexpected with respect to swine flu
}

$\mathrm{T}$ op influenza control officials from Mexico, Canada and the United States warn that the Novel A(H1N1) influenza pandemic may intensify further, while a vaccine won't be available in Canada until November.

"The epidemic curve hasn't shown any sign of peaking. We really don't know what's coming," Frank Plummer, scientific director general for the Public Health Agency of Canada, told more than a 1000 infectious disease specialists gathered from 2 dozen countries at the 26th International Congress of Chemotherapy and Infection in Toronto, Ontario on June 18.

"It's too soon to let down our guard on this," Plummer later added in an interview.

With the World Health Organization (WHO) having declared the $\mathrm{A}(\mathrm{H} 1 \mathrm{~N} 1)$ flu the first pandemic in 41 years and with almost half of Canada's nearly 6000 cases now in Ontario, Plummer says his agency is bracing for a surge during the fall, when children go back to school.

Nancy Cox, director of the influenza division with the US Centers for Disease Control in Atlanta, Georgia, warned that although a vaccine was shipped to manufacturers for production on May 12, it will not be commercially available during the coming winter flu season in the southern hemisphere.

"We've learned the lesson that there is actually a lot of influenza circulating through the noninfluenza season," said Cox, who noted that $\mathrm{A}(\mathrm{H} 1 \mathrm{~N} 1)$ has been identified in over 70 countries with over 50000 cases confirmed and 280 deaths.

The Centers for Disease Control has isolated the Novel $\mathrm{A}(\mathrm{H} 1 \mathrm{~N} 1)$ virus and made a candidate vaccine virus that can be used to create vaccine, Cox explained. But commercial production and global distribution of the vaccine will take at least "several more months" to complete.

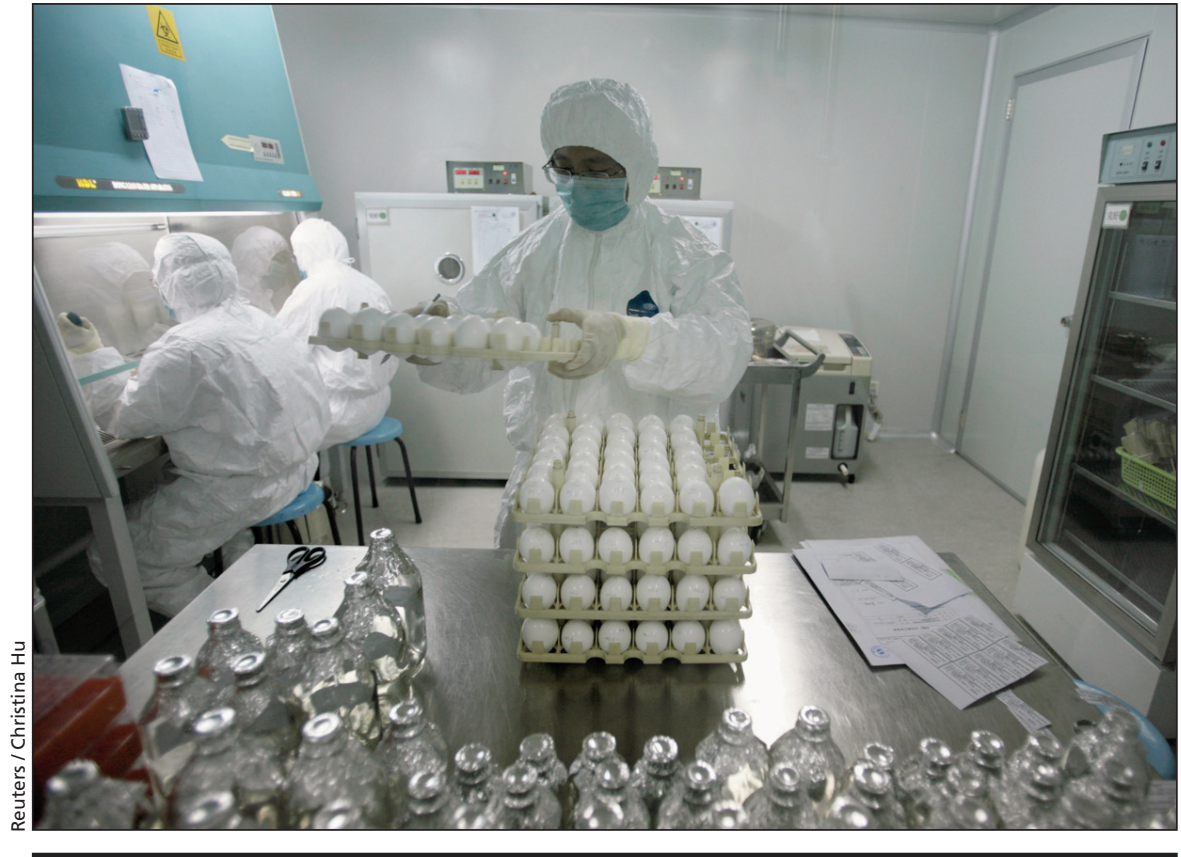

A technician holds a tray of eggs during production of a vaccine for the $A(H 1 N 1)$ flu virus in Beijing, China.

On June 12, Switzerland-based Novartis International $\mathrm{AG}$ announced that a first batch of $\mathrm{A}(\mathrm{H} 1 \mathrm{~N} 1)$ vaccine was prepared using an innovative approach that is faster than traditional production with eggs. Novartis hopes to have approval to begin shipping the vaccine in the fall.

The Public Health Agency of Canada says the earliest that a vaccine could be available in Canada is November (www.phac-aspc.gc.ca/alert-alerte/swine -porcine/faq_rg_swine-eng.php).

Mexico, Canada and the United States have been the hardest hit so far, with the spread of the virus now gathering speed in Australia, Chile, Japan and the United Kingdom (see map, www.who.int/csr /don/h1n120090622_0800.png)

"This very rapidly hit global scale," said Cox. But there is no evidence of a resurgence or 'second wave' of illness in Mexico, the Public Health Agency of Canada said.

Celia Alpuche, deputy director of Mexico's Instituto de Diagnóstico y
Referencia Epidemiológicos, the country's main reference laboratory, noted that the Novel A(H1N1) crisis has alerted WHO and the Global Health Security Initiative to the need for universal free flu vaccines.

"People were not interested in this until recently," Alpuche said. "But I know people will be, after this."

Alpuche called attention to the need to protect flu strains as "public goods" free from proprietary control, echoing Cox's emphasis on the use of public domain genomics in the production of a candidate vaccine at the Centers for Disease Control.

The Novel A(H1N1) crisis has highlighted the need for transparency and nondiscriminatory international cooperation, Alpuche said, while praising the Public Health Agency of Canada for its intensive effort to identify the virus and help Mexico equip and operate a testing facility capable of running 1000 tests a day within its first week in operation. 
Alpuche also credited Canada's experience with severe acute respiratory syndrome for the Public Health Agency of Canada's intensive response to her appeals for help in April. The virus was first identified in Canada after Alpuche shipped samples to Winnipeg, Manitoba, aboard Mexican President Felipe Calderón's airplane.

Alpuche noted that the first Mexican case of swine flu involved a 6-monthold infant in San Luis Potosi and was not associated with a pig farm, as was widely reported. Even so, Cox emphasized that pig farming played a central role in the emergence of the virus. "Pigs are the ideal reassortment vessels," she said. "And we have a tremendous gap in surveillance in pigs and farm workers. There are many unanswered questions about pigs."

Cox noted that ongoing intensive analysis of the virus indicates no evi- dence of resistance to widely used antivirals. And although there is evidence that Novel A(H1N1) has greater virulence than seasonal H1N1, Cox said tests on ferrets show that respiratory transmission is lower than for seasonal H1N1.

"Novel H1N1 may not be fully adopted to humans," said Cox. "We're looking to the southern hemisphere for clues. Unfortunately, they are not going to have a vaccine as we do that."

Cox added that key challenges for public health agencies now are to get the vaccine out, to establish what populations to target the vaccine toward, to establish the timing of a fall wave and to monitor for a potential reassortment of $\mathrm{A}(\mathrm{H} 1 \mathrm{NI})$.

Some $51 \%$ of fatalities are people aged 25-64, said Cox, adding that asthma and obesity seem to be the most frequent comorbidities. "This is very worrying," she warned.

In Canada, Plummer notes, it is
Novel A(H1N1) that is hitting First Nations people with unusual severity. In some parts of the United States, the Centers for Disease Control says that as much as $7 \%$ of the population was infected, with about half those cases estimated to have been acquired in a health care setting.

There is also substantial concern the Novel A(H1N1) virus could reassort, possibly with $\mathrm{H} 5 \mathrm{~N} 1$, which would render a vaccine useless, Plummer says. "We don't have a good idea why it's more severe in some people than in others. But having a virus to work on drives our downstream research."

Mount Sinai microbiology head Don Low also says the Novel A(H1N1) virus is quite likely to reassort: "This a virus that is built to make mistakes." Paul Webster, Toronto, Ont.

DOI:10.1503/cmaj.091176 